\title{
UJI AKTIVITAS KOMBINASI EKSTRAK AIR LIDAH BUAYA( Aloe vera L.) DAN AKAR MANIS (Glycyrrhiza glabra L.) SEBAGAI PENYUBUR RAMBUT
}

\section{TEST ACTIVITIES OF COMBINATION OF ALOE VERA (Aloe vera L.) AND LIQUORICE (Glycyrrhiza glabra L.) ROOTS WATER EXTRACT AS HAIR FERTILIZER}

\author{
Sulistiorini Indriaty ${ }^{1}$, Teti Indrawati ${ }^{2}$, Shelly Taurhesia ${ }^{2}$ \\ ${ }^{1}$ Akademi Farmasi Muhammadiyah Cirebon \\ Jl. Cideng Indah no. 3 Cirebon \\ ${ }^{2}$ Fakultas Farmasi Universitas Pancasila \\ Jl. Srengseng sawah,jagakarsa, Jakarta \\ Email: lovely_kalila@yahoo.co.id
}

Submitted: 10-12-2015 Reviewed: 01-12-2015

Accepted: 26-04-2016

\begin{abstract}
ABSTRAK
Tanaman lidah buaya (Aloe vera L.) dengan kandungan asam amino, vitamin, asam folat, dan akar manis ( Glycyrrhiza glabra L) mengandung glisirizin, dan flavonoid, yang mempunyai khasiat sebagai penyubur rambut. Penelitian ini bertujuan untuk mendapatkan kombinasi ekstrak dengan aktivitas penyubur rambut yang paling optimal. Ekstrak tanaman diperoleh dengan metode maserasi menggunakan penyari air. Ekstrak dikombinasi dengan komposisi: komposisi 1 (ekstrak air akar manis konsentrasi $2,5 \%$ dan lidah buaya 7,5\%), kombinasi 2 (ekstrak air akar manis konsentrasi 2,5\% dan lidah buaya 2,5\%), dan kombinasi 3 (ekstrak air akar manis konsentrasi 5\% dan lidah buaya 7,5\%). Kombinasi ekstrak tersebut diberikan pada hewan uji kelinci sebanyak 4 ekor selama 28 hari. Aktivitas penyubur rambut dinyatakan sebagai laju pertumbuhan rambut, percepatan pertumbuhan rambut dan bobot rambut kelinci selama 28 hari. Hasil pertumbuhan rambut kelinci menunjukkan kombinasi 1 memiliki rata-rata panjang rambut yang terbesar dengan nilai laju pertumbuhan rambut $2,97 \mathrm{~cm}$, percepatan pertumbuhan rambut sebesar $0,15 \mathrm{~cm} /$ hari pada hari ke 7 dan berat rambut 0,13 gram.
\end{abstract}

Kata kunci: Aloe vera L., Glycyrrhiza glabra L., laju pertumbuhan rambut, percepatan pertumbuhan rambut, bobot rambut

\begin{abstract}
Aloe vera (Aloe vera $\mathrm{L}$.) contains amino acids, vitamins, folic acid, and liquorice (Glycyrrhiza glabra L) containing glisirizin, and flavonoids, which have properties as fertilizer hair. This study aims to obtain a combination of extracts with activity most optimal fertilizer hair, made 3 combination with a combination of 1 (the water extract of liquorice concentration of $2.5 \%$ and $7.5 \%$ aloe vera), a combination of 2 (the water extract of liquorice concentrations of 2, 5\% and $2.5 \%$ aloe vera), and combinations of 3 (the water extract of liquorice concentration of $5 \%$ and $7.5 \%$ aloe vera). Testing the activity of hair growth is done by measuring the rate of hair growth, hair growth acceleration and weight of rabbit hair for 28 days. Rabbit hair growth results showed the combination 1 has an average length of the largest hair with hair growth rate value of $2.97 \mathrm{~cm}$, accelerated hair growth amounted to $0.15 \mathrm{~cm} /$ day on day 7 and weighing 0.13 gram hair.
\end{abstract}

Keywords: Aloe vera L., Glycyrrhiza glabra L., rate of hair growth, hair growth accelerating, weight of hair 


\section{PENDAHULUAN}

Kerontokan rambut merupakan masalah yang umum dialami oleh semua kalangan usia. Salah satu cara pencegahan kerontokan rambut dapat dilakukan dengan melakukan perawatan rambut (Tranggono dan Latifah, 2007). Beberapa tanaman dapat digunakan untuk mengatasi kerontokan rambut diantaranya adalah lidah buaya dan akar manis. Kedua tanaman tersebut secara empirik telah digunakan untuk perawatan rambut. Berdasarkan penelitian yang telah dilakukan ekstrak hidroalkohol Aloe vera $5 \%$ memiliki aktivitas sebagai penumbuh rambut pada tikus, dengan pertumbuhan rambut lebih baik dari pada tikus kontrol negatif (basis) dengan aplikasi selama satu bulan (Jain, 2011).

Demikian juga akar manis merupakan bahan yang digunakan sebagai penumbuh rambut. Berdasarkan hasil penelitian yang telah dilakukan, ekstrak petrolium eter akar manis $1 \%$ berpotensi sebagai anti androgenik alopecia dengan kontol positif finasteride (Sukirti, 2013). Selain itu ekstrak petrolium eter akar manis $2 \%$ menunjukkan pertumbuhan rambut yang lebih baik dibandingkan dengan kontrol positif minoxidil (Sukirti, 2012).

Pada penelitian ini dibuat 3 kombinasi ekstrak air lidah buaya dan akar manis yaitu dengan kombinasi 1 (ekstrak air akar manis konsentrasi 2,5\% dan lidah buaya 7,5\%), kombinasi 2 (ekstrak air akar manis konsentrasi 2,5\% dan lidah buaya 2,5\%), dan kombinasi 3 (ekstrak air akar manis konsentrasi 5\% dan lidah buaya 7,5\%). Dari penelitian ini ingin diketahui kombinasi ekstrak manakah yang memiliki aktivitas pertumbuhan rambut yang paling optimal dengan mungukur laju pertumbuhan rambut, percepatan pertumbuhan rambut dan bobot rambut dengan menggunakan kelinci sebagai hewan uji.

\section{METODE PENELITIAN Alat dan Bahan}

Alat yang digunakan adalah timbangan analitik AND HR 20, alat pencukur rambut, viskometer Ostworld, $\mathrm{pH}$ meter Toledo, jangka sorong, dan alat-alat gelas. Bahan yang digunakan yaitu serbuk ekstrak air lidah buaya (Java plant), serbuk ekstrak air akar manis (Java plant), etanol 96\% (Pro Teknis CV. Mustika Lab), propilenglikol (Pro Teknis CV. Mustika Lab), mentol (Pro Teknis CV. Mustika Lab), metil paraben (Pro Teknis CV. Mustika Lab), Natrium Metabisulfit (Pro Teknis CV. Mustika Lab) dan aqua destilata (Pro Teknis CV. Mustika Lab), hair tonic merk X dengan nomor Batch 187021 Exp. Juli 2016.

\section{Hewan uji}

Hewan uji yang digunakan adalah kelinci jantan putih usia 3-4 bulan dengan bobot badan 2-3 $\mathrm{kg}$. Jumlah kelinci putih jantan yang dibutuhkan dalam penelitian ini ditentukan dengan menggunakan rumus empiris Federer, $(\mathrm{n}-1)(\mathrm{t}-1) \geq 15$, dimana t menunjukkan jumlah perlakuan dan $\mathrm{n}$ merupakan jumlah hewan tiap perlakuan (Juhaeni , 2014; Priskila, 2012). Berdasarkan rumus Federer maka hewan uji yang digunakan adalah 4 ekor kelinci putih jantan.

\section{Jalannya Penelitian}

\section{Pembuatan larutan kombinasi ekstrak akar manis dan lidah buaya}

Dalam $1 \mathrm{~kg}$ ekstrak kering mengandung $80 \%$ lidah buaya dan $20 \%$ maltrodektrin dan $1 \mathrm{~kg}$ ekstrak kering mengandung $75 \%$ akar manis dan 25\% maltrodektrin. Pembuatan larutan kombinasi ekstrak air lidah buaya dan akar manis dilakukan sebagai berikut:

a. Kombinasi 1 (ekstrak air akar manis konsentrasi 2,5\% dan lidah buaya 7,5\%) dibuat dengan cara melarutkan ekstrak akar manis 3,33 gram dan ekstrak lidah buaya 9,38 gram dilarutkan dengan aquades hingga $100 \mathrm{~mL}$.

b. Kombinasi 2 (ekstrak air akar manis konsentrasi 2,5\% dan lidah buaya 2,5\%) dibuat dengan cara melarutkan ekstrak akar manis 3,33 gram dan ekstrak lidah buaya 3,13 gram dilarutkan dengan aquades hingga $100 \mathrm{~mL}$.

c. Kombinasi 3 ( ekstrak air akar manis konsentrasi 5\% dan lidah buaya 7,5\%) dibuat dengan cara melarutkan ekstrak akar manis 6,67 gram dan ekstrak lidah buaya 9,38 gram dilarutkan dengan aquades hingga $100 \mathrm{~mL}$. 


\section{Persiapan hewan uji}

Hewan uji diadaptasikan selama seminggu setelah itu punggung kelinci di buat enam area perlakuan dengan lebar 2,5x2,5 $\mathrm{cm}$ dan jarak antar area $1 \mathrm{~cm}$. Kemudian dilakukan pencukuran rambut kelinci pada enam area tersebut, diteruskan dengan pengolesan etanol $70 \%$ sebagai antiseptik.

\section{Uji aktivitas penyubur rambut}

Pengujian aktivitas penyubur rambut kombinasi ekstrak akar manis dan lidah buaya dilakukan dengan cara diteteskan dua kali sehari yaitu pada pagi dan sore hari masing-masing $1 \mathrm{~mL}$ pada tiap daerah pengolesan. Pengamatan dilakukan selama 28 hari dengan mengambil enam helai rambut kelinci pada tiap area pengolesan setiap tujuh hari sekali yaitu hari ke-7, ke-14, ke-21, dan ke-28 . Hari pertama pengolesan dianggap hari ke-0. Rambut diambil dengan cara digunting, kemudian diluruskan dan diletakkan pada alas berwarna gelap, serta diselotip dan diukur dengan menggunakan jangka sorong. Pada hari ke-28, semua rambut di tiap area dipotong dan ditimbang beratnya. Terdapat enam area perlakuan yaitu kombinasi 1, kombinasi 2, kombinasi 3, kontrol positif, kontrol negatif, dan kontrol normal. Kontrol positif yang digunakan adalah salah satu sediaan penumbuh rambut yang ada di pasaran, kontrol negatif yang digunakan aquades, dan kontrol normal tidak diolesi apapun. Pada tiap kelinci yang digunakan dilakukan pengacakan posisi perlakuan (Purwantini, 2008).

\section{Analisis Data}

Evaluasi penelitian pada laju pertumbuhan rambut dilakukan dengan mengolah data laju pertumbuhan rambut perminggu secara statistik. Uji Homogenitas dan Normalitas dilakukan dilanjutkan dengan uji ANOVA, Kruskall Wallis dan Uji Mann Whitney dengan taraf kepercayaan $95 \%$.

\section{HASIL DAN PEMBAHASAN}

Laju pertumbuhan rambut kelinci yang diberi kombinasi ekstrak pada hari ke-0 sampai ke-28 dapat dilihat pada Tabel I dan Gambar 1.

Hasil uji aktivitas pertumbuhan rambut kelinci menunjukkan kombinasi I memiliki rata-rata panjang rambut yang lebih panjang. Pada Tabel I kombinasi $1(2,97 \pm 0,08)$ terlihat pada hari ke-28 mempunyai panjang rambut yang lebih besar dibandingkan kombinasi $2(2,82 \pm 0,53)$ dan kombinasi 3 $(2,37 \pm 0,48)$. Hal ini dikarenakan komposisi kombinasi 1 mengandung ekstrak air lidah buaya 7,5\% dan ekstrak air akar manis 2,5\%. Kombinasi dua ekstrak ini diduga memiliki aktivitas yang sinergis terhadap pertumbuhan rambut. Aktivitas penyubur rambut pada kombinasi ekstrak akar manis dan lidah buaya disebabkan karena lidah buaya mengandung senyawa lignin dan polisakarida yang berguna sebagai media pembawa zat-zat nutrisi yang diperlukan oleh kulit dan memiliki tingkat keasaman $(\mathrm{pH})$ yang normal, hampir sama dengan $\mathrm{pH}$ kulit manusia, sehingga meningkatkan kemampuan penetrasi nutrisi untuk memperbaiki akar rambut, menguatkan dan memicu pertumbuhan rambut. Lidah buaya juga memiliki kandungan asam amino yang berfungsi untuk membantu perkembangan sel-sel baru dengan kecepatan luar biasa dan menghilangkan sel-sel yang telah mati dari epidermis (Bassetti, 2005). Selain itu lidah buaya juga dapat melembabkan epidermis, antibakteri, dan melembutkan rambut (Kumar, 2010). Kandungan isoflavon, steroid glisirizin dan asam gliziritik pada akar manis memiliki aktivitas seperti estrogen dan dapat menurunkan kadar testoteron (Grant, 2012). Fitosterol menghambat perubahan testoteron menjadi dihidrotestoteron sehingga dapat digunakan untuk mengatasi alopesia androgenic (Sukirti, 2012). Estrogen dapat memodifikasi metabolisme androgen dalam subunit folikel rambut yang berbeda, sehingga dapat mengurangi kadar 5 - $\alpha$-dihidrotestoteron, serta mempengaruhi faktor pertumbuhan dan transkripsi sitokin (hormon yang berperan dalam pertumbuhan normal rambut) (Ohnemus, 2006).

Rata-rata panjang rambut sampai hari ke-28 menunjukkan data homogen tetapi tidak terdistribusi normal sehingga analisis statistik menggunakan uji Kruskal Wallis dan dilanjutkan uji Mann Whitney. Hasil uji menunjukkan terdapat perbedaan bermakna $(\mathrm{p}<0,05)$ pada kontrol normal dibandingkan dengan kombinasi 1,2 , dan 3 , hal ini menunjukkan adanya pertumbuhan rambut yang 
signifikan secara statistik pada ketiga kombinasi pada hari ke-28 bila dibandingkan dengan kontrol normal. Data statistik menunjukkan perbedaan bermakna $(\mathrm{p}<0,05)$ pada rata-rata panjang rambut antar kombinasi dengan kontrol positif pada hari ke-28. Hal ini menunjukkan bahwa semua kombinasi pada hari ke-28 memiliki aktivitas pertumbuhan rambut, tetapi efektivitasnya tidak sama dibandingkan dengan kontrol positif. Perbandingan antara masing-masing kombinasi 1, kombinasi 2 dan kombinasi 3 , menyatakan tidak terdapat perbedaan secara bermakna $(\mathrm{p}>0,05)$ antar kombinasi. Dengan demikian kombinasi 1 dengan konsentrasi ekstrak air lidah buaya 7,5\% dan ekstrak air akar manis 2,5\% merupakan kombinasi yang paling efektif hingga hari ke-28. Percepatan pertumbuhan rambut kelinci dapat dilihat pada Tabel II.

Tabel I. Laju pertumbuhan rambut kelinci yang diberi kombinasi ekstrak pada hari ke-0 sampai hari ke-28

\begin{tabular}{lcccc}
\hline & \multicolumn{4}{c}{ Panjang rambut $(\mathrm{cm}) \pm \mathrm{SD}$} \\
\cline { 2 - 5 } Perlakuan & Hari ke-7 & Hari ke-14 & Hari ke-21 & Hari ke-28 \\
\hline Kombinasi 1 & $1,04 \pm 0,22$ & $1,26 \pm 0,33$ & $2,03 \pm 0,26$ & $2,97 \pm 0,08$ \\
Kombinasi 2 & $0,95 \pm 0,08$ & $1,47 \pm 0,31$ & $2,24 \pm 0,21$ & $2,82 \pm 0,53$ \\
Kombinasi 3 & $0,99 \pm 0,13$ & $1,73 \pm 0,40$ & $2,00 \pm 0,52$ & $2,37 \pm 0,48$ \\
Normal & $0,75 \pm 0,13$ & $1,02 \pm 0,19$ & $1,24 \pm 0,27$ & $1,48 \pm 0,12$ \\
Positif & $0,81 \pm 0,08$ & $0,94 \pm 0,08$ & $1,16 \pm 0,05$ & $1,54 \pm 0,22$ \\
Negatif & $0,85 \pm 0,06$ & $0,96 \pm 0,07$ & $1,12 \pm 0,16$ & $1,52 \pm 0,17$ \\
\hline
\end{tabular}

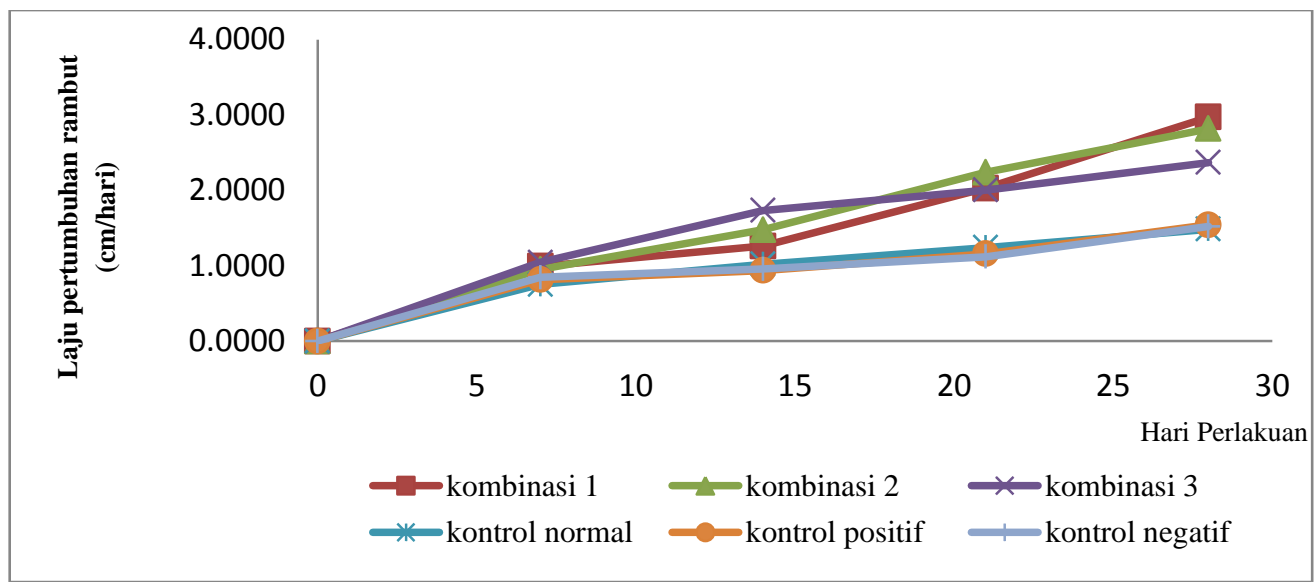

Gambar 1. Grafik laju pertumbuhan rambut kelinci yang diberi kombinasi ekstrak pada hari ke 0 sampai 28

Tabel II. Percepatan pertumbuhan rambut yang diberi kombinasi ekstrak lidah buaya dan akar manis

\begin{tabular}{lccccc}
\hline & \multicolumn{5}{c}{ Laju pertumbuhan rambut $(\mathrm{cm} /$ hari $)$} \\
\hline Perlakuan & hari ke-0 & hari ke-7 & hari ke-14 & hari ke-21 & hari ke-28 \\
\hline Kombinasi 1 & 0 & 0,15 & 0,09 & 0,09 & 0,11 \\
Kombinasi 2 & 0 & 0,14 & 0,11 & 0,11 & 0,10 \\
Kombinasi 3 & 0 & 0,14 & 0,12 & 0,09 & 0,08 \\
Normal & 0 & 0,11 & 0,07 & 0,06 & 0,05 \\
Positif & 0 & 0,12 & 0,07 & 0,06 & 0,06 \\
Negatif & 0 & 0,12 & 0,07 & 0,05 & 0,05 \\
\hline
\end{tabular}


Percepatan pertumbuhan rambut yang diberi kombinasi ekstrak air lidah buaya dan akar manis dibandingkan kontrol normal dapat dilihat pada Gambar 2.

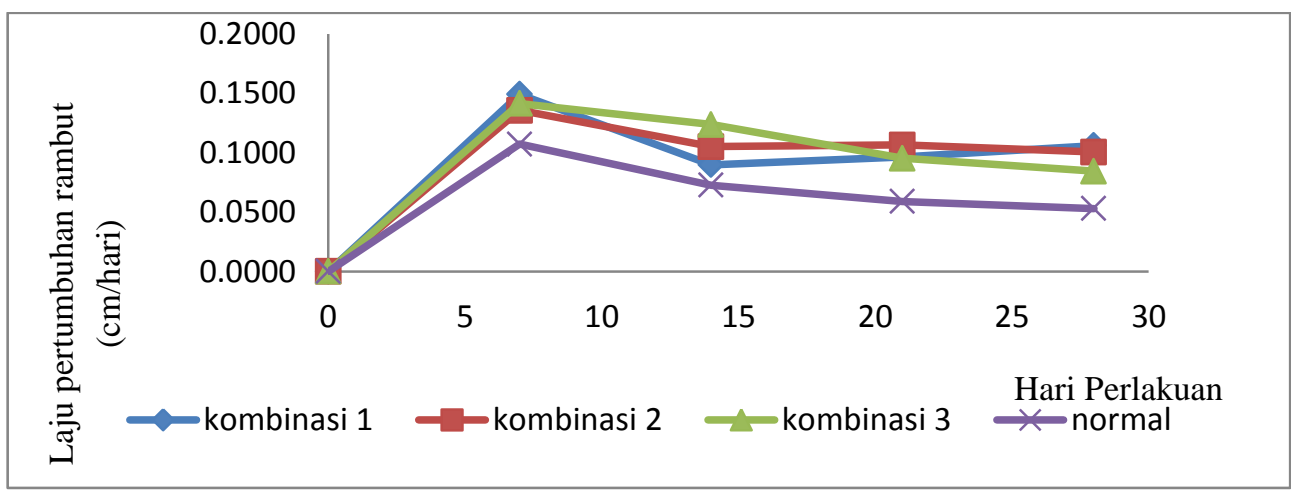

Gambar 2. Grafik percepatan pertumbuhan rambut yang diberi kombinasi ekstrak air lidah buaya dan akar manis dibandingkan kontrol normal

Percepatan pertumbuhan rambut yang diberi kombinasi ekstrak dibandingkan kontrol positif dapat dilihat pada Gambar 3.

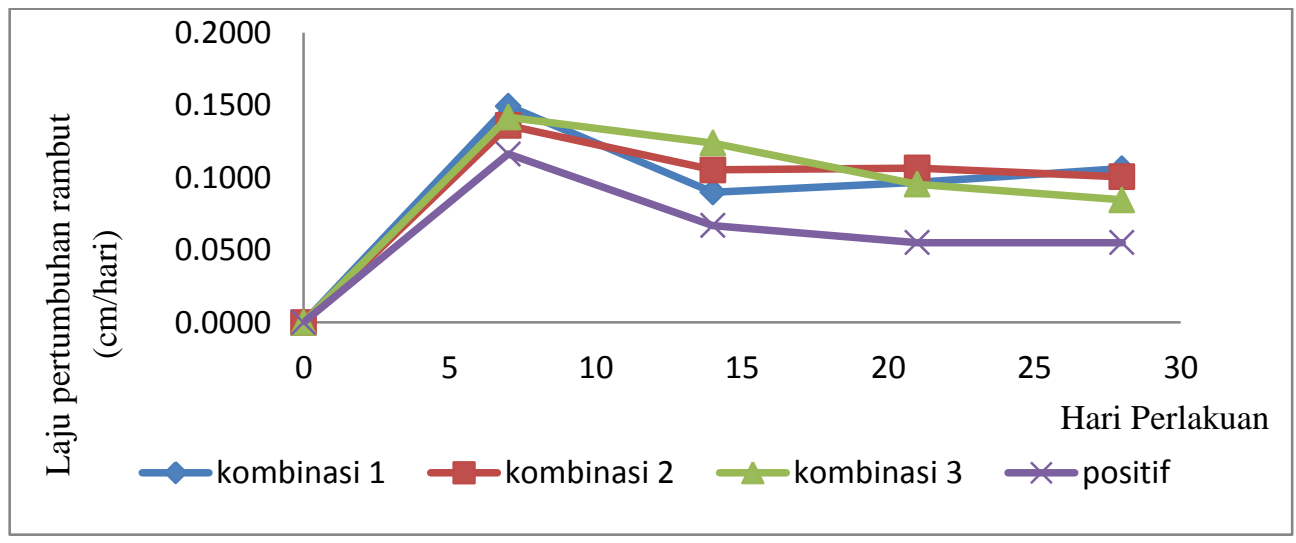

Gambar 3. Grafik percepatan pertumbuhan rambut yang diberi kombinasi ekstrak air lidah buaya dan akar manis dibandingkan kontrol positif

Percepatan pertumbuhan rambut yang diberi kombinasi ekstrak dibandingkan kontrol negatif dapat dilihat di Gambar 4.

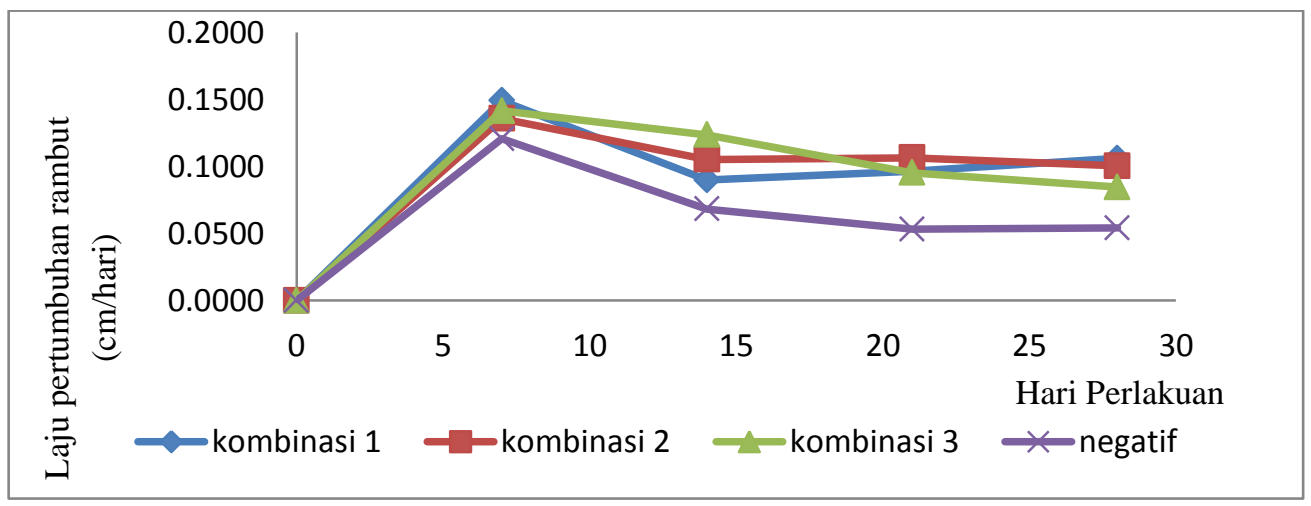

Gambar 4. Grafik percepatan pertumbuhan rambut yang diberi kombinasi ekstrak air lidah buaya dan akar manis dibandingkan kontrol negatif 
Berdasarkan gambar di atas percepatan pertumbuhan rambut pada kontrol normal, kontrol negatif, kontrol positif, maupun semua kombinasi ekstrak memiliki pola yang hampir sama yaitu mengalami peningkatan percepatan pertumbuhan rambut dari hari ke-0 hingga hari ke-7. Percepatan pertumbuhan rambut kombinasi $1(0,15 \mathrm{~cm} /$ hari $)$ lebih besar dibandingkan kombinasi $2(0,14 \mathrm{~cm} / \mathrm{hari})$, kombinasi $3(0,14 \mathrm{~cm} /$ hari $)$, kontrol normal $(0,11 \mathrm{~cm} / \mathrm{hari})$, kontrol positif $(0,12 \mathrm{~cm} / \mathrm{hari})$, kontrol negatif $(0,12 \mathrm{~cm} / \mathrm{hari})$. Pada hari ke- 0 , semua area perlakuan pada punggung kelinci dibersihkan rambutnya sehingga belum terjadi pertumbuhan rambut. Pada hari ke-7 hingga ke-28 semua kontrol mengalami penurunan percepatan pertumbuhan rambut dengan penurunan yang tajam terjadi pada hari ke-7 hingga ke-14. Semua kombinasi ekstrak mengalami penurunan percepatan pertumbuhan rambut pada hari ke-7 hingga hari ke-14, tetapi kombinasi 1 mengalami peningkatan percepatan pada hari ke14 hingga ke-28. Kombinasi 2 mengalami peningkatan percepatan pada hari ke-14 hingga hari ke-21 tetapi pada hari ke-21 hingga hari ke-28 mengalami penurunan kecepatan pertumbuhan rambut. Kombinasi 3 mengalami penurunan percepatan pertumbuhan rambut dari hari ke-7 hingga hari ke-28.

Bobot rambut kelinci yang diberi kombinasi ekstrak pada hari ke-0 sampai ke-28 dapat dilihat pada Gambar 5.

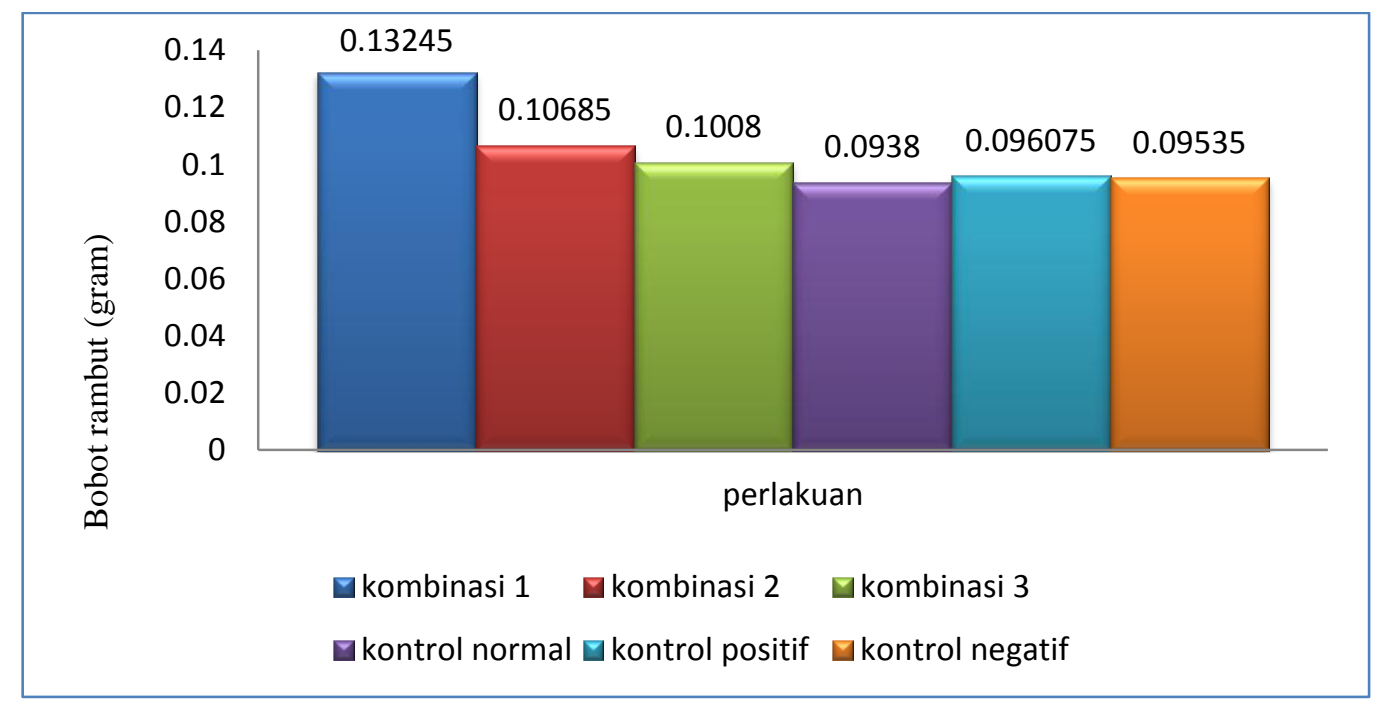

\section{Gambar 5. Diagram batang bobot rambut kelinci yang diberi kombinasi ekstrak pada hari ke 28}

Bobot rambut kelinci pada diagram di atas menunjukkan ekstrak kombinasi $1(0,1325 \pm 0,0182)$ memiliki bobot yang terbaik dan diikuti dengan kombinasi $2(0,1069 \pm 0,0208)$ dan 3 $(0,1008 \pm 0,0179)$. Semua kombinasi ekstrak memiliki bobot rambut yang lebih besar dibandingkan control positif $(0,0961 \pm 0,0186)$, kontrol negative $(0,0954 \pm 0,0067)$, dan kontrol normal $(0,0938 \pm 0,0161)$ sehingga semua kombinasi tersebut memiliki aktivitas untuk meningkatkan bobot rambut kelinci lebih baik dari pada semua kontrol. Rambut 65-95\% mengandung protein dan protein tersebut merupakan kondensasi polimer dari asam amino (Robbins, 2012). Aloe vera mengandung 20 jenis asam animo yang dibutuhkan untuk perbaikan dan pertumbuhan rambut (Kumar, 2010) dan bermanfaat untuk meningkatkan ukuran folikel rambut (Dutt, 2002).

Hasil statistik rata-rata berat rambut kelompok perlakuan berdistribusi normal dan homogen sehingga dilanjutkan dengan uji ANOVA. Uji ANOVA menunjukkan terdapat perbedaan bermakna dari berat rambut masing-masing kelompok perlakuan dilanjutkan dengan uji Mann Whitney bahwa hanya kombinasi 1 yang memiliki perbedaan signifikan terhadap kontrol normal, dan negatif.

\section{KESIMPULAN}

Kombinasi ekstrak air akar manis dan lidah buaya memiliki aktivitas sebagai penyubur rambut dengan kombinasi 1 memiliki rata-rata panjang rambut yang terbesar dengan nilai laju pertumbuhan 
rambut yang $2,97 \mathrm{~cm}$, percepatan pertumbuhan rambut sebesar $0,15 \mathrm{~cm} /$ hari pada hari ke 7 dan berat rambut 0,13 gram.

\section{DAFTAR PUSTAKA}

Bassetti, A., Sale, S. 2005. The Great Aloe Book, first edition. Zuccari edition. USA. 45

Dutt, B., 2002, A study of Patenting Activity in Aloe vera, Jurnal of Intelectual Property Rights.7:335.

Grant, P., Shamin R., 2012, An Update on Plant Derived Anti-Androgens, International jurnal of Endocrinology Metabolism. 10(2):497-502.

Jain, R., Neetesh K.J., Namrata, S., Gnanachandran, A.K., Gokulan, P.D., 2011, Development And Evaluation Of Polyherbal Ointment For Hair Growth Activity, International Journal of Pharmacy and Pharmaceutical. 3( 2):180-182.

Juheini, A., Esther L.P.S., Anwar, E., Djajadisastra, J., 2014, Green Tea (Camellia Sinensis, L.) Ethanolic Extract as Hair Tonic in Nutraceutical:Physical Stability, Hair Growth Activity on Rats, and Safety Test, International Journal of Pharmacy and Pharmaceutical Sciences. 6 (5). 94-99.

Kumar K.P.S., Debjit B., Chiranjib, B., 2010, Aloe vera: A Potential Herb and its Medicinal Importance, Journal of Chemical and Pharmaceutical Research 2(1): 21-29.

Ohnemus, U., Uenalan M., 2006, The Hair Follicle as an Estrogen Target and Source, The Endrocrine Society. 27(6): 677-706.

Priskila, V., 2012. Uji stabilitas fisik dan uji aktivitas pertumbuhan rambut tikus putih jantan dari sediaan hair tonik yang mengandung ekstrak air bonggol pisang kepok (musa balbisiana) (Skripsi). Depok : Fakultas MIPA. Program studi farmasi.28

Purwantini, I., Rima, M., Naniek, D.B.S., 2008, Combination Of Teh And Mangkokan Leaves Extract To Promote Hair Growth, Traditional Medicine Journal. 13(43)

Robbins, C.R. 2012. Chemical and Physical Behavior of Human Hair. Springer-Verlag Berlin Heidelberg.106

Sukirti, U., Ashoke K.G., Vijender, S., 2012, Hair Growth Promotant Activity of Petroleum Ether Root Extract of Glycyrrhiza Glabra L (Fabaceae) in Female Rats, Tropical Journal of Pharmaceutical Research. October.11(5):753-758.

Sukirti, U.,Vijender, S., 2013, Potentiality Of Petroleum Ether $(60-80)^{\circ} \mathrm{C}$ Extract Of Glycyrrhiza Glabra On Androgenic Alopecia, Asian Journal Pharmaceutical and Clinical Research. 6 (3) :52-55.

Tranggono, R.I., Latifah, F. 2007. Buku Pegangan Ilmu Pengetahuan Kosmetik. Jakarta: Gramedia Pustaka Utama. 38 
